\title{
Digestible lysine for barrows of genetic lines selected for meat deposition from 60 to 100 days of age
}

\section{Douglas Haese $^{1}$, Juarez Lopes Donzele $^{2}$, Rita Flávia Miranda de Oliveira ${ }^{2}$, Alysson Saraiva ${ }^{3}$, Francisco Carlos de Oliveira Silva ${ }^{4}$, João Luís Kill ${ }^{1}$, Márvio Lobão Teixeira de Abreu ${ }^{5}$}

\author{
1 Departamento de Medicina Veterinária/UVV. \\ 2 Departamento de Zootecnia/UFV. \\ ${ }^{3}$ Doutorando em Zootecnia, DZO/UFV. \\ 4 EPAMIG. \\ ${ }^{5}$ Departamento de Zootecnia/UFLA.
}

\begin{abstract}
In order to evaluate the effects of dietary digestible lysine levels on performance and carcass traits of two genetic lines of pigs selected for meat deposition, from 60 to 100 days of age, a total of 120 crossbred barrows, with initial average body weight of $25.42 \pm 2.08 \mathrm{~kg}$ were used. Pigs were allotted in a complete randomized block design, within a $4 \times 2$ factorial arrangement (four digestible lysine levels: 0.90, 1.00, 1.10, and 1.20\%, and two genetic lines: A and B), with five replicates and three pigs per pen, which was the experimental unit. There was no interaction between genetic and digestible lysine levels for any variable of performance and carcass traits assessed. There was also no effect of digestible lysine levels in feed intake, body weight gain, and feed conversion. Digestible lysine intake of pigs increased linearly with increasing digestible lysine levels in the diets. Except for carcass yield that increased quadratically up to $1.04 \%$ estimate level of digestible lysine, there was no effect of lysine levels on the other carcass traits assessed (loin and ham yield, and amount of meat in the carcass). The digestible lysine level of $0.90 \%$, corresponding to an estimated daily intake of $19.10 \mathrm{~g}$, meets the requirements of castrated male pigs selected for meat deposition from both genetic lines, from 60 to 100 days of age.
\end{abstract}

Key Words: amino acids, growing, nutrition, requirement

\section{Introduction}

Barrows with different genetic potential for lean tissue deposition have varied nutrient requirements and demand specific feeding strategies (Friesen et al., 1994). The assessment of the nutritional requirements of barrows from different genetic groups at specific production stages is essential to obtain the maximum expression of the genetic potential for meat production in livestock animals.

Modern genetic strains of pigs have great potential for muscle deposition, a feature that highly interferes in the demand of amino acids, especially lysine. Lysine is the first limiting amino acid in corn-soybean meal basal diet and it is directly responsible for muscle deposition due to its constancy in the body protein and its preferential deposition in lean tissues (Kessler, 1998). Therefore, performance and lean gain responses in pigs may be associated with the level of dietary lysine (Oliveira et al., 2003).

The continuous selection of pigs with high muscle deposition potential has resulted in an increased demand for digestible lysine (Loughmiller et al., 1998) and companies are constantly offering new and improved genetic strains with increased potential for meat production. Further studies to determine the requirements of digestible lysine for the new strains are, therefore, continually required to guarantee animal performance.

This study assessed the effect of lysine levels on performance and carcass characteristics of barrows from two genetic lines selected for meat deposition from 60 to 100 days of age.

\section{Material and Methods}

The experiment was conducted at Setor de Suinocultura in Departamento de Zootecnia, Universidade Federal de Viçosa (UFV), Viçosa, Minas Gerais, Brazil.

A total of 120 barrows selected for muscle deposition, with initial weight of $25.42 \pm 2.08 \mathrm{~kg}$, was allotted to a $4 \times 2$ factorial-randomized block design (4 lysine levels: $0.90,1.00,1.10$ and $1.20 \%$ and 2 genetic lines: A and B), with five replicates and three pigs per experimental unit (pen). The criteria used for block formation were initial weight and genetic group.

The animals were housed in pens equipped with semiautomatic feeders and nipple drinkers, in a concrete floor facility with with ceramic tiling. Indoor temperature was 
daily measured (at 8 a.m.) with maximum and minimum thermometers.

Experimental diets (Table 1) were corn-soybean meals based supplemented with minerals and vitamins to meet the nutritional requirements for this animal category, except for lysine, according to Rostagno et al. (2005).

Treatments consisted of a basal diet and 3 diets supplemented with different levels of L-lysine HCL in replacement of starch.

Ratios between lysine and other amino acids in the diets were checked in all treatments to guarantee that no other amino acid was limiting in the diet. The assessment of the amino acids ratios in the diets was done using the ratios recommended by Rostagno et al. (2005) in the ideal protein concept for growing barrows.

The animals received water and experimental diet ad libidum during the experimental period. They were weighed at the beginning and at the end of the experiment (60 and 100 days, respectively) to determine average daily feed intake, average daily weight gain, feed conversion and digestible lysine intake. Daily feed waste was weighed to calculate feed and digestible lysine intake.

At the end of the experiment, after 24 hours of fasting, one pig from each experimental unit with body weight closest to the average weight of the block was exsanguinated, shaved and eviscerated. The carcasses was then processed to estimate carcass yield (expressed as percentage of hot carcass weight in relation to body weight after fasting), ham yield (expressed as percentage of the total ham weight in relation to chilled half-carcass weight), loin yield (expressed as percentage of total loin weight in relation to chilled half-carcass weight). Meat yield was obtained by applying value of ' $\mathrm{Y}$ ' on the equation: $\mathrm{Y}=15.32+(1.272 * \mathrm{THM})+(1.654 * \mathrm{TCM})$ on the carcass weight, where THM is the total ham meat percentage (primary cuts + flaps and muscle) and TCM is the total carré meat percentage (loin and flaps).

Data were analyzed using procedures for analysis of variance and regression in the System for Statistics and Genetics (SAEG), developed at the Universidade Federal de Viçosa (UFV, 2000), version 9.0. A 0.05 critical level of probability for type I error was used for all statistical procedures.

\section{Results and Discussion}

The maximum and minimum mean temperatures registered inside the facility were $14.7 \pm 2.24^{\circ} \mathrm{C}$ and $21.1 \pm 1.83^{\circ} \mathrm{C}$, respectively. Considering the ideal temperature range from 16 to $24^{\circ} \mathrm{C}$ for pigs in the growing

Table 1 - Percentage and calculated composition of experimental diets

\begin{tabular}{|c|c|c|c|c|}
\hline \multirow[t]{2}{*}{ Ingredient } & \multicolumn{4}{|c|}{ Digestible lysine levels (\%) } \\
\hline & 0.90 & 1.00 & 1.10 & 1.20 \\
\hline Corn & 63.888 & 63.888 & 63.888 & 63.888 \\
\hline Soybean meal & 30.000 & 30.000 & 30.000 & 30.000 \\
\hline Soybean oil & 1.000 & 1.000 & 1.000 & 1.000 \\
\hline Starter nucleus ${ }^{1}$ & 4.000 & 4.000 & 4.000 & 4.000 \\
\hline Starch & 1.100 & 0.883 & 0.596 & 0.210 \\
\hline $\mathrm{L}$-lysine $\mathrm{HCl}$ & - & 0.120 & 0.247 & 0.375 \\
\hline DL-methionine & 0.012 & 0.057 & 0.120 & 0.188 \\
\hline $\mathrm{L}$-threonine & - & 0.052 & 0.120 & 0.188 \\
\hline $\mathrm{L}$-tryptophan & - & - & 0.019 & 0.038 \\
\hline $\mathrm{L}$-isoleucine & - & - & 0.010 & 0.068 \\
\hline $\mathrm{L}$-valine & - & - & - & 0.051 \\
\hline Butyl-hidroxy-toluene & 0.010 & 0.010 & 0.010 & 0.010 \\
\hline \multicolumn{5}{|c|}{ Calculated nutritional composition ${ }^{2}$} \\
\hline $\operatorname{ME}(\mathrm{kcal} / \mathrm{kg})$ & 3200 & 3200 & 3200 & 3200 \\
\hline Crude protein (\%) & 18.973 & 18.973 & 18.973 & 18.973 \\
\hline Digestible lysine (\%) & 0.907 & 1.000 & 1.100 & 1.200 \\
\hline Digestible tryptophan (\%) & 0.190 & 0.190 & 0.209 & 0.228 \\
\hline Digestible met + cis $(\%)$ & 0.564 & 0.622 & 0.684 & 0.746 \\
\hline Digestible threonine $(\%)$ & 0.619 & 0.670 & 0.737 & 0.804 \\
\hline Digestible isoleucine (\%) & 0.617 & 0.617 & 0.627 & 0.684 \\
\hline Digestible valine (\%) & 0.801 & 0.801 & 0.801 & 0.801 \\
\hline Calcium (\%) & 0.665 & 0.665 & 0.665 & 0.665 \\
\hline Available phosphorus (\%) & 0.345 & 0.345 & 0.345 & 0.345 \\
\hline
\end{tabular}

${ }^{1}$ Provided per kg of product: vitamin A - 93,000 UI; vitamin D3 - 24,000 UI; vitamin E - $106 \mathrm{mg}$; vitamin K3 - $53 \mathrm{mg}$; thiamin - $13.3 \mathrm{mg}$; pantothenic acid - $173 \mathrm{mg}$; biotin - $0.42 \mathrm{mg}$; pyridoxine - $13.3 \mathrm{mg}$; vitamin $\mathrm{B} 6 \mathrm{HCl}-8.8 \mathrm{mg}$; folic acid - $520 \mu \mathrm{g}$; vitamin B12 - $7.000 \mathrm{mg}$; calcium (minimum) - $112 \mathrm{~g}$; phosphorus (minimum) - $27 \mathrm{~g}$; sodium - $58.5 \mathrm{~g}$; iron $-1,820 \mathrm{mg}$; zinc $-2,049 \mathrm{mg}$; copper $-2,126 \mathrm{mg}$; manganese $-836 \mathrm{mg}$; iodine $-29.5 \mathrm{mg}$; fluorite (maximum) - $485 \mathrm{mg}$; selenium - $8 \mathrm{mg}$; cobalt $-3.6 \mathrm{mg}$.

${ }^{2}$ Values estimated based on the digestibility coefficients of amino acids of ingredients, according to Rostagno et al. (2005). 
phase (30 to $60 \mathrm{~kg}$ ) suggested by Coffey et al. (2000), the pigs in this study did not go through heat stress.

No interaction was found ( $\mathrm{P}>0.05)$ between the levels of lysine and genetic lines in relation to performance and the carcass traits evaluated.

No effect $(\mathrm{P}>0.05)$ of the levels of digestible lysine on daily feed intake (DFI) was observed and there was no variation $(\mathrm{P}>0.05)$ in DFI between animals from different genetic lines (Table 2), showing that the DFI was not a variable between different genetic lines. The absence of effect of the levels of lysine in diets on the DFI of growing pigs (30 to $60 \mathrm{~kg}$ ) was also observed by several authors (Fontes et al.,2000; Gasparotto et al., 2001; Abreu et al., 2007; Souza et al., 2008, Main et al., 2008; Zangeronimo et al., 2009; Fortes, 2009).

According to Ettle \& Roth (2004), pigs are able to recognize diets containing different concentrations of tryptophan and prefer those with the most appropriate levels of this amino acid, showing increased consumption. However, the consistency of the studies on the absence of effect of lysine levels on the DFI of pigs shows that, unlike tryptophan, pigs do not change their consumption to meet lysine requirements. In agreement with this proposition, Owen et al. (1994) evaluated diets with different lysine levels $(0.50,1.10$, and $1.60 \%)$ in a free choice feeding system and found that pigs were unable to regulate consumption according to lysine concentration.

This is in agreement with the report by Edmonds \& Baker (1987), who showed that pigs can tolerate a considerable excess of amino acids in the diet, especially lysine, with no significant variation in consumption.

D'Mello (1993) and Kerr et al. (2003) have shown that diets with unbalanced amino acids can result in reduced intake by pigs. This unbalance may have been avoided in this study by diet supplementation with synthetic amino acids, keeping the ratios between these amino acids and lysine.

A significant effect $(\mathrm{P}<0.01)$ of digestible lysine levels on daily lysine intake (DLI) of animals was observed
(Table 2) with linear increase, according to the equation $\hat{\mathrm{Y}}=3.2309+18.0837 \mathrm{X}\left(\mathrm{r}^{2}=0.95\right)$. Other authors (Abreu et al., 2007; Fortes, 2009) have observed linear increase of lysine consumption in growing pigs ( 30 to $60 \mathrm{~kg}$ ) as a result of increasing levels of this amino acid in diets. In this study, the daily diet intake of animals had no significant variation among treatments, so the linear increase observed in the DLI can be explained by the concentration of this amino acid in the diet.

The levels of lysine had no influence $(\mathrm{P}>0.05)$ on the daily weight gain (ADG) of animals, regardless of genetic line (Table 2). Several authors in studies with growing pigs have also reported no influence of dietary lysine levels on ADG (Maiden et al. 1994; Souza, 1997, Fontes et al., 2000, Fontes et al. 2005; Abreu et al. 2007; Fortes, 2009; Zangeronimo et al., 2009).

However, Warnants et al. (2003) and Main et al. (2008) assessed pigs from 30 to $50 \mathrm{~kg}$ and from 43 to $70 \mathrm{~kg}$, respectively, and found that animal weight gain showed quadratic increase up to the highest estimated levels of digestible lysine (0.91 and $1.09 \%$ ).

The amino acid demands of pigs can be affected by different factors such as ambient temperature and immune challenge levels (Williams et al., 1997; Braumann et al., 2002; LeFloc'h et al., 2004; Trevisi et al., 2009). Besides these factors, the inconsistency in the daily weight gain response resulting from the lysine levels observed among the studies may be related to differences in the genetic potential for lean gain of pigs. According to Sthaly et al. (1994), the response of ADG to dietary lysine level depends on the animal genotype and growth potential. Yen et al. (1986) affirms that performance and carcass meat deposition responses may be associated with the level of dietary lysine demand due to a higher demand of this amino acid for protein deposition and its high concentration in the muscle tissue of pigs.

Consistent with these assertions, Gasparotto et al. (2001) evaluated the lysine requirement of barrows from two genetic groups (genetically improved and common groups), from $24-50 \mathrm{~kg}$ and found that lysine levels of 1.00 and $0.75 \%$ met

Table 2 - Performance of barrows from 60 to 100 days of age in relation to the level of lysine in diets

\begin{tabular}{|c|c|c|c|c|c|c|c|}
\hline \multirow[t]{2}{*}{ Variable } & \multicolumn{4}{|c|}{ Digestible lysine level, \% } & \multicolumn{2}{|c|}{ Genetic } & \multirow[t]{2}{*}{$\mathrm{CV}, \%$} \\
\hline & 0.90 & 1.00 & 1.10 & 1.20 & A & B & \\
\hline Initial body weight, $\mathrm{kg}$ & 25.63 & 25.40 & 25.40 & 25.27 & 25.67 & 25.22 & 0.14 \\
\hline Daily weight gain, $\mathrm{g}$ & 1000 & 1012 & 1017 & 998 & 988 & 1024 & 4.26 \\
\hline Daily feed intake, $g$ & 2156 & 2114 & 2157 & 2048 & 2114 & 2123 & 4.79 \\
\hline Feed conversion, g/g & 2.15 & 2.09 & 2.12 & 2.05 & 2.14 & 2.08 & 3.73 \\
\hline
\end{tabular}

${ }^{1}$ Linear $(\mathrm{P}<0.05)$; $\mathrm{CV}=$ Coefficient of variation. 
the animals' requirements of both groups (improved and common, respectively).

No significant variation in weight gain in animals from different genetic strains was observed in this study. This may have contributed to the fact that there was no difference in the digestible lysine requirements between them.

No significant differences were found between ADI and ADG of the animals, that is why no effect was observed $(\mathrm{P}>0.05)$ for dietary lysine levels in diets on feed conversion (Table 2), in spite of genetics. Similar results of feed conversion obtained in this study were found by Gasparotto et al. (2001), Haese et al. (2006) and Strong (2009) who evaluated lysine levels in diets for barrows from 30 to $60 \mathrm{~kg}$, and also found no significant effect on this variable.

The effects of lysine levels on the performance of growing pigs were investigated by Fontes et al. (2000), Warnants etal. (2003), Oliveira etal. (2006), Abreuetal. (2007), Main et al. (2008) and Zangeronimo et al. (2009), who reported significant variation in feed conversion, as a function of dietary lysine concentrations in diets.

From the performance results obtained in the present study it can be affirmed that pigs from the different genetic lines showed similar weight gain potential and feed efficiency, which explains the absence of significant interactions between levels of lysine and genetics.

The $0.90 \%$ level of digestible lysine, corresponding to a daily intake of $19.0 \mathrm{~g}$ (genetic A) and $19.1 \mathrm{~g}$ (genetic B), meets the requirements of $\mathrm{ADG}$ and feed conversion of both genetic groups and is consistent with the $19.12 \mathrm{~g} / \mathrm{d}$ value proposed by Rostagno et al. (2005) for growing barrows (30 to $50 \mathrm{~kg}$ ) with high genetic potential. However, this value $(0.90 \%)$ is higher than the level of $0.80 \%$ digestible lysine, intake of $16.6 \mathrm{~g}$, obtained by Fortes (2009) in a study with pigs from two genetic lines selected for lean deposition between 63 and 103 days of age.

The digestible lysine levels influenced $(\mathrm{P}<0.05)$ carcass yield (CY) (Table 3 ), showing a quadratic increase up to the highest level of 1.04\% lysine (Figure 1). Genetic group had no influence on this variable. Yen et al. (2005) and Abreu et al. (2007) also found positive responses on carcass yield of pigs in relation to dietary lysine concentrations in studies with finishing pigs. However, Cromwell et al. (1993), Friesen et al. (1994) and De La Llata et al. (2002) found no influence of levels of dietary lysine on carcass traits of pigs.

Lysine levels had no influence $(\mathrm{P}<0.05)$ on loin and ham yield (Table 3 ). Similar results were obtained by Cromwell et al. (1993), Souza Filho et al. (1999), De La Llata et al. (2002) and Abreu et al. (2007), who assessed lysine levels for growing and finishing barrows and found no effect of dietary lysine levels on the loin-eye area and depth or on loin and ham yield. Likewise, Fabian et al. (2001) and Kendall et al. (2001), in studies with pigs weighing $50-80 \mathrm{~kg}$ and $70-93 \mathrm{~kg}$, respectively, found that the levels of lysine did not influence animal carcass traits.

The levels of dietary lysine had no effect $(\mathrm{P}>0.05)$ on the meat content of carcass (Table 3). Similarly, Abreu et al. (2007) evaluated levels of digestible lysine on carcass traits from pigs weighing 60 to $95 \mathrm{~kg}$ and found no effect on lean meat

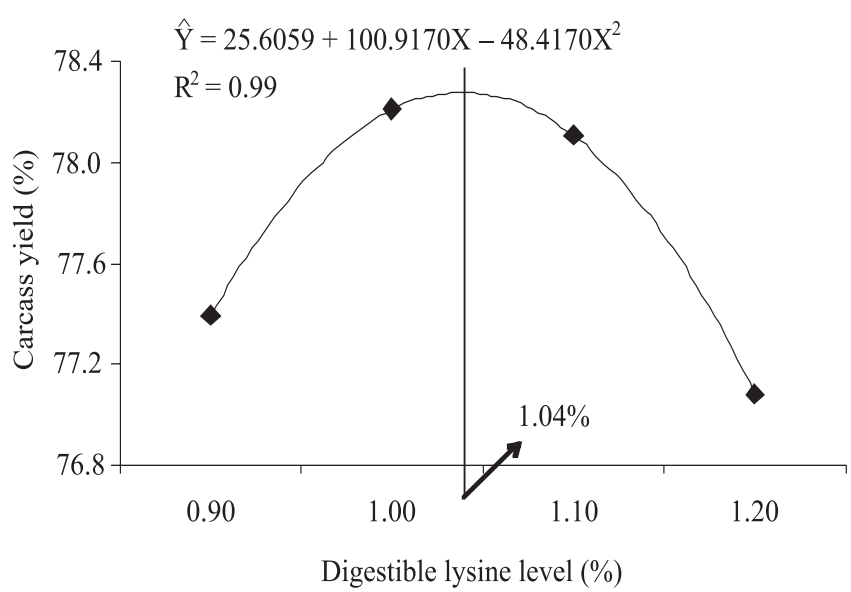

Figure 1 - Effect of digestible lysine levels in diets on carcass yield of barrows from 60 to 100 days of age.

Table 3 - Carcass traits for barrows between 60 and 100 days of age, as a function of digestible lysine levels in diet

\begin{tabular}{|c|c|c|c|c|c|c|c|}
\hline \multirow[t]{2}{*}{ Variable } & \multicolumn{4}{|c|}{ Digestible lysine level, \% } & \multicolumn{2}{|c|}{ Genetic line } & \multirow[t]{2}{*}{$\mathrm{CV}, \%$} \\
\hline & 0.90 & 1.00 & 1.10 & 1.20 & A & B & \\
\hline Carcass yield $(\%)^{1}$ & 77.39 & 78.21 & 78.11 & 77.08 & 78.21 & 77.30 & 1.63 \\
\hline Loin yield $(\%)$ & 5.62 & 5.80 & 5.36 & 5.70 & 5.62 & 5.63 & 6.72 \\
\hline Ham yield (\%) & 30.73 & 31.35 & 30.82 & 30.45 & 30.64 & 31.04 & 2.95 \\
\hline Total ham meat $(\%)^{2}$ & 19.80 & 20.44 & 19.65 & 20.10 & 19.76 & 20.24 & - \\
\hline Total carré meat $(\%)^{3}$ & 8.32 & 8.59 & 8.43 & 8.59 & 8.50 & 8.47 & - \\
\hline Amount of meat $(\mathrm{kg})^{4}$ & 26.36 & 27.20 & 26.34 & 26.63 & 26.47 & 26.81 & 6.07 \\
\hline
\end{tabular}

${ }_{1}$ Quadratic $(\mathrm{P}<0.05)$.

2 Total ham meat percentage (main cuts + flaps and muscle).

3 Total carré meat percentage (loin and flaps).

${ }^{4}$ Obtained by applying the ' $\mathrm{Y}$ ' value from the equation $\mathrm{Y}=15.32+(1.272 * \mathrm{THM})+(1.654 * \mathrm{TCM})$ on the carcass weight.

$\mathrm{CV}=$ Coefficient of variation 
yield. Fontes et al. (2000), who assessed gilts from 30 to $60 \mathrm{~kg}$ and Kill et al. (2003), in a study with finishing pigs, also found no effect of lysine levels on the muscle growth rate of pigs.

On the other hand, Oliveira et al. (2006), Abreu etal. (2007) and Nunes et al. (2008) found significant effect of the dietary lysine levels on protein deposition in the carcass of growing barrows ( 6 to $60 \mathrm{~kg}$ ). According to Kill et al. (2003) and Abreu at al. (2007), the inconsistency of the results found in studies examining the effects of increasing levels of dietary lysine on carcass traits of pigs may be related, among other factors, to the genotypic differences concerning meat deposition potential. This is in agreement with the results found by Gasparotto et al. (2001) and Moreira et al. (2002), who evaluated the lysine requirement of barrows from two genetic groups (common and improved) from 24 to $50 \mathrm{~kg}$ and 50 to $90 \mathrm{~kg}$, respectively. They found that the levels of lysine influenced loin-eye area and depth, which varied between the genetic groups.

Assessing the influence of genotype, sex and lysine levels on carcass quality of pigs, Unruh et al. (1996) found that the increase in lysine concentration had minimal effects on carcass traits, which is consistent with the results of carcass traits obtained in this study.

\section{Conclusions}

The $0.90 \%$ level of digestible lysine, corresponding to a daily intake of $19.10 \mathrm{~g}$, meets the requirements of 60-100-day-old barrows selected for meat deposition, from both genetics.

\section{References}

ABREU M.L.T.; DONZELE J.L.; OLIVEIRA, R.F.M. et al. Níveis de lisina digestível em rações, utilizando-se o conceito de proteína ideal, para suínos machos castrados de alto potencial genético, dos 30 aos $60 \mathrm{~kg}$. Revista Brasileira de Zootecnia v.36, p.62-67, 2007.

BRAUMANN, B.G.; BILKEI, G.; CACÉRES, L. et al. Efeito del diferente contenido em lisina de la dieta en el rendimiento del cerdo postdestete. Anaporc, 2002. (CD-ROM).

COFFEY, R.D.; PARKER, G.R.; LAURENT, K.M. Feeding growing-finishing pigs to maximize lean grow rate. University of Kentucky. College of Agriculture, 2000. Available at: $<$ http://www.animalgenome.org/edu/PIH/prod_grow_finish.pdf $>$ Accessed on: May 14, 2007.

CROMWELL, G.L.; CLINE, T.R.; CRENSHAW, J.D. The dietary protein and (or) lysine requirements of barrows and gilts. Journal of Animal Science, v.71, n.6, p.1510-1519, 1993.

D'MELLO, J.P.F. Amino acid supplementation of cereal-based diets for non-ruminants. Animal Feed Science and Technology, v. 45, p. $1-18,1993$.

DE La LLATA, M.; DRITZ, S.S.; TOKACH, M.D. et al. Effects of increasing 1-lysine $\mathrm{HCl}$ in corn- or sorghum-soybean mealbased diets on growth performance and carcass characteristics of growing-finishing pigs. Journal of Animal Science, v. 80 n.9, p.2420-2432, 2002.

DONZELE, J.L.; FREITAS, R.T.F.; OLIVEIRA, R.F.M. et. al. Níveis de lisina para leitoas de 30 a $60 \mathrm{~kg}$ de peso vivo. Revista da Sociedade Brasileira de Zootecnia, v.24, p.967-973, 1994.

EDMONDS, M.S. BAKER, D.H. Aminoacids excesses for young pigs: Effects of excess methionine, tryptophan, threonine or leucine. Journal of Animal Science, v.64, p.1664-1671, 1987.

ETTLE, T.; ROTH, F.X. Specific selection for tryptophan by the piglet. Journal of Animal Science, v.82, p.1115-1121, 2004.

FABIAN, J.; CHIBA, L.I.; KUHLERS, L.T. et al. Effect of genotype and dietary lysine content during the grower phase on growth performance, serum urea $\mathrm{N}$, and carcass and meat quality. Journal of Animal Science, v.79, p.67, 2001 (suppl. 1)

FONTES, D.O.; DONZELE, J.L.; OLIVEIRA, R.F.M. et al. Níveis de lisina para leitoas selecionadas geneticamente para deposição de carne magra, dos 30 aos $60 \mathrm{~kg}$, mantendo constante a relação entre lisina e metionina + cistina, treonina, triptofano, isoleucina e valina. Revista Brasileira de Zootecnia, v.29, p.776-783, 2000.

FONTES, D.O.; DONZELE, J.L.; OLIVEIRA, R.F.M. et al. Níveis de lisina para leitoas selecionadas geneticamente para deposição de carne magra na carcaça, dos 30 aos $60 \mathrm{~kg}$. Revista Brasileira de Zootecnia, v.34, p.81-89, 2005.

FORTES, E.I. Níveis de lisina digestível e planos de nutrição para suínos machos castrados de duas linhagens genéticas. 2009. 46f. Dissertação (Mestrado em Zootecnia) Universidade Federal de Viçosa, Viçosa, MG.

FRIESEN, K.G.; NELSSEN, J.L.; GOODBAND, R.D. et al. Influence of dietary lysine on growth and carcass composition of high-lean-growth gilts fed from 34 to 72 kilograms. Journal of Animal Science, v.72, p.1761-1770, 1994.

GASPAROTTO, L.F.; MOREIRA, I.; FURLAN, C.A. Exigência de lisina, com base no conceito de proteína ideal, para suínos machos castrados de dois grupos genéticos, na fase de crescimento. Revista Brasileira de Zootecnia, v.30, p.1742-1749, 2001.

HAESE, D.; SARAIVA, A.; DONZELE, J.L. et al. Exigência de lisina digestível para suínos machos castrados mestiços de duas linhagens comerciais dos 60 aos 100 dias de idade. In: CONGRESSO LATINO-AMERICANO DE SUINOCULTURA, 3., 2006, Foz do Iguaçu. Anais... Foz do Iguaçu, 2006. (CD-ROM).

KENDALL, D.C.; ALLEE, G.L.; USRY, J.L. Evaluation of synthetic L-lysine use in finishing pigs. Journal of Animal Science, v.79, p.65, 2001 (suppl. 1).

KERR, B.J.; YEN, J.T.; NIENABER, J.A. et al. Influence of dietary protein level, amino acid supplementation and environmental temperature on performance, body composition, organ weights and total heat production of growing pigs. Journal of Animal Science, v.81, p.1998-2007, 2003

KESSLER, A.M. Exigências nutricionais para máximo rendimento de carne em suínos. In: SIMPÓSIO SOBRE RENDIMENTO E QUALIDADE DA CARNE SUÍNA, 1998, Concórdia. Anais... Concórdia: EMBRAPA-CNPSA, 1998. p.18-25.

KILL, J.L.; DONZELE, J.L.; OLIVEIRA, R.F.M. et al. Níveis de lisina para leitoas de alto potencial genético para deposição de carne magra dos 65 aos $95 \mathrm{~kg}$. Revista Brasileira de Zootecnia, v.32, p.1647-1656, 2003.

LE FLOC'H. N.; MELCHIOR, D.; OBLED, C. Modifications of protein and amino acid metabolism during inflammation and immune system activation. Livestock Production Science, v.87, p.37-45, 2004.

MAIN, R.G.; DRITZ, S.S.; TOKACH, M.D. et al. Determining an optimum lysine:calorie ratio for barrows and gilts in commercial finishing facility. Journal of Animal Science, v.86, p.2190-2207, 2008.

MOREIRA, I.; GASPAROTTO, L.F.; FURLAN, A.C. et al. Exigência de lisina para machos castrados de dois grupos genéticos de suínos na fase de terminação, com base no conceito de proteína ideal. Revista Brasileira de Zootecnia, v.31, p.96-103, 2002 . 
NUNES, C.G.V.; OLIVEIRA, R.F.M.; DONZELE, J.L. et al. Níveis de lisina digestível para leitões dos 6 aos $15 \mathrm{~kg}$. Revista Brasileira de Zootecnia, v.37, p.84-88, 2008.

OLIVEIRA, A.L.S.; DONZELE, J.L.; OLIVEIRA, R.F.M. et al. Exogência de suínos machos castrados de alto potencial genético para deposição de carne magra na carcaça dos 15 aos $30 \mathrm{~kg}$. Revista Brasileira de Zootecnia, v.36, p.2338-2343, 2006.

OLIVEIRA, A.L.S.; DONZELE, J.L.; OLIVEIRA, R.F.M. et al. Lisina em rações para suínos machos castrados selecionados para deposição de carne magra na carcaça dos 95 aos $110 \mathrm{~kg}$. Revista Brasileira de Zootecnia, v.32, p.337-343, 2003.

OWEN, K.Q.; KNABE, D.A.; BURGOON, K.G. Self-selection of diets and lysine requirements of growing-finishing swine. Journal of Animal Science, v.72 p.554-564, 1994.

ROSTAGNO, H.S.; ALBINO, L.F.T.; DONZELE, J.L. et al. Tabelas brasileiras para aves e suínos: composição de alimentos e exigências nutricionais. Viçosa, MG: DZO/UFV, 2005. 141p.

SOUZA FILHO, G.A.; LIMA, J.A.F.; FIALHO, E.T. et al. Efeito de planos de nutrição e de genótipos sobre características físicas de carcaça de suínos. In: REUNIÃO ANUAL DA SOCIEDADE BRASILEIRA DE ZOOTECNIA, 36., 1999, Porto Alegre. Anais... Porto Alegre: Sociedade Brasileira de Zootecnia, 1999. (CD-ROM).

SOUZA, A.M. Exigências nutricionais de lisina para suínos mestiços, de 15 a 95 kg de peso. 1997. 81f. Dissertação (Mestrado em Zootecnia) - Universidade Federal de Viçosa, Viçosa, MG.

SOUZA, L.P.O.; FONTES, D.O.; ROSA, B.O. et al. Níveis de lisina digestível para suínos machos castrados de alto potencial genético para deposição de carne magra de 60 a 95 dias de idade. In: PORK EXPO E SIMPÓSIO INTERNACIONAL DE SUINOCULTURA, 4., 2008, Curitiba. Anais... Curitiba, 2008. (CD-ROM).

STAHLY, T.S.; WILLIAMNS, N.H.; SWENSON, S. Impact of genotype and dietary regimen on growth of pigs from 6 to $25 \mathrm{~kg}$. Journal of Animal Science, p.72-165, 1994 (suppl. 1).
TREVISI, P.; MELCHIOR, D.; MAZZONI, M. et al. A tryptophanenriched diet improves feed intake and growth performance of susceptible weanling pigs orally challenged with Escherichia coli K88. Journal of Animal Science, v.87, p.148-156, 2009.

UNIVERSIDADE FEDERAL DE VIÇOSA - UFV. SAEG Sistemas de análises Estatísticas e Genéticas. Viçosa, MG: UFV, 2000. (Versão 8.0).

UNRUH, J.A.; FRIESEN, K.G.; STUEWE, S.R. The influence of genotype, sex, and dietary lysine on pork sbprimal cut yields and carcass quality of pigs fed to either 104 or 127 kilograms. Journal of Animal Science, v.74, p.1274-1283, 1996.

WARNANTS, N.; Van OECKEL, M.J.; PAEPE, M. Response of growing pigs to different levels of ileal standardized digestible lysine using diets balanced in threonine, methionine and tryptophan. Livestock Production Science, v.82, p.201-209, 2003.

WILLIAMS, N.H.; STAHLY, T.S.; ZIMMERMAN, D.R. Effect of chronic immune system activation on the rate, efficiency, and composition of growth and lysine needs of pigs fed from 6 to $27 \mathrm{~kg}$. Journal of Animal Science, v.75, p.2463-2471, 1997.

YEN, H.T.; COLE, D.J.A.; LEWIS, D. Amino acid requirements of growing pigs. 7. The response of pigs from 25 to $55 \mathrm{~kg}$ live weight to dietary ideal protein. Animal Production, v.43, p.141-154, 1986 .

YEN, J.T.; KLINDT, J.; KERR, B.J. et al. Lysine requirement of finishing pigs administered porcine somatotropin by sustainedrelease implant. Journal of Animal Science, v.83, p.2789-2797, 2005.

ZANGERONIMO, M.G.; FIALHO, E.T.; LIMA, J.A.F. et al. Desempenho e características de carcaça de suínos dos 20 aos $50 \mathrm{~kg}$ recebendo rações com reduzido teor de proteína bruta e diferentes níveis de lisina digestível verdadeira. Ciência Rural, v.39, p.1507-1513, 2009. 